\title{
CIVIL ENFORCEABILITY OF RELIGIOUS ANTENUPTIAL AGREEMENTS
}

Orthodox and Conservative Judaism regard marriage and divorce as institutions of religious significance. ${ }^{1}$ In almost all jurisdictions a civilly valid marriage can be concluded by either a secular or a religious ceremony. ${ }^{2}$ But a civilly valid divorce can be obtained only in a secular court. ${ }^{3}$ Such a secular divorce is not recognized by Judaism as a valid dissolution of the marriage. ${ }^{4}$ Thus, while a religious marriage ceremony will satisfy both religious and civil authorities, ${ }^{5}$ two divorce proceedings are necessary to sever the Jewish marriage ties. ${ }^{6}$ The religious community may regard remarriage as adultery if a religious divorce has not been obtained. ${ }^{7}$

The Jewish religion regards divorce as a unilateral act by the husband; a marriage is dissolved when a husband repudiates his wife by giving her a bill of divorcement. ${ }^{8}$ Originally, this power of the husband was absolute ${ }^{9}$ except (1) where he falsely accused his bride of antenuptial incontinence, ${ }^{10}$ or (2)

${ }^{1}$ Consult, e.g., Mielziner, The Jewish Law of Marriage and Divorce 25-26 (1884) (hereafter cited as Mielziner); see Pope Pius XI, Encyclical Letter on Christian Marriage, printed in The Ass'n of American Law Schools, Selected Essays on Family Law 132 (1950), to compare a Christian viewpoint.

${ }^{2}$ E.g., III. Rev. Stat. (1953) c. $89, \$ 4$. The only exception is Maryland, where a religious ceremony of marriage is required: Md. Code Ann. Art. 62, $\$ 4$ (1951) ; Denison v. Denison, 35 Md. 361 (1871).

${ }^{3}$ E.g., Chertok v. Chertok, 208 App. Div. 161, 203 N.Y. Supp. 163 (1st Dep't, 1924).

4 Consult, e.g., Horowitz, The Spirit of Jewish Law 293 (1953) (hereafter cited as Horowitz).

'Authorities cited note 2 supra.

-Authorities cited notes 3 and 4 supra.

" Consult Horowitz 293.

${ }^{3}$ Deuteronomy 24: 1-2. Consult Horowitz 258, 273. The procedure involved in issuing a religious divorce is as follows: Before the divorce proceedings take place, a reconciliation is attempted. Consult Sheftelowitz, The Jewish Law of Family and Inheritance and its Application in Palestine 114 (undated) (hereafter cited as Sheftelowitz). Failing this, the religious divorce is prepared. The husband makes no protestations of religion or religious beliefs. He merely expresses his will to divorce his wife, and authorizes a scribe to prepare a bill of divorcement which is to be written specifically for him and for her for the sake of a divorce. The divorce instrument identifies the two parties to the marriage and expresses the will of the husband to repudiate and release his wife. The only signatures on the bill of divorce are those of two male witnesses, each to be an observant Jew over the age of 13 and not related to each other or to the parties. The divorce is valid when the husband gives the instrument to his wife personally or through an agent. Consult Horowitz 278-81.

- Consult Horowitz 273; Scheftelowitz 111.

${ }^{10}$ Deuteronomy 22:13-19. 
where he raped her before marriage. ${ }^{11}$ This absolute right has been limited, ${ }^{12}$ but because it originates in the Bible it cannot be directly challenged. Thus, one such limitation was made around the year 1000, when it was ruled that the wife's consent to accept the divorce must be obtained ${ }^{13}$ - a ruling still in effect today. ${ }^{14}$ However, though the giver of a divorce in violation of this ruling is subject to ecclesiastical censure, the divorce is still valid..$^{15}$ Further, a husband may marry again without obtaining a divorce-though he may be censured because polygamy has been prohibited by rabbinical ruling. ${ }^{16}$ If the wife remarries without a religious divorce, however, under Jewish law she is an adulteress. ${ }^{17}$

Except by applying moral, religious, and social pressure, a Jewish court is powerless to force a husband to grant, or a wife to accept, a religious divorce. Civilly divorced parties have been able to take advantage of the situation and demand waiver of alimony rights or other financial concessions from the spouse in return for a religious divorce. To afford the parties (especially the wife ${ }^{18}$ ) some protection, the Rabbinical Assembly of America, representing Conservative Judaism in America, adopted a resolution to include the following clause in the Ketubah (the Jewish marriage contract):

[W]e, the bride and bridegroom ... hereby agree to recognize the Beth Din [rabbinic court] of the Rabbinical Assembly and The Jewish Theological Seminary of America, or its duly appointed representatives, as having authority to counsel us in the light of Jewish tradition which requires husband and wife to give each other complete love and devotion, and to summon either party at the request of the other, in other to enable the party so requesting to live in accordance with the standards

"I Ibid.

${ }^{12}$ For example, the husband's absolute right to divorce his wife was further limited in the Talmud in case of her insanity, during her captivity, or during her minority. By making the entire procedure of executing and delivering a bill of divorcement very formal and technical, the Talmud effectively subjected the husband's right to divorce his wife to rabbinical supervision and thereby to rabbinical control. Consult Horowitz 273-74.

${ }^{23}$ Consult Horowitz 274, quoting part of this ruling: Response of Rabbenu Gershom.

It Consult Scheftelowitz 71.

${ }^{15}$ Consult Scheftelowitz 111. Under certain conditions, however, the husband may be given permission to remarry by a group of one hundred rabbis even though the wife does not consent to accepting a divorce, e.g., where the wife is insane, or where she acts directly contrary to the decision of a Beth Din (rabbinic court). Under these conditions the husband is given permission to take a second wife while provision is made that a bill of divorce will be given to the wife when she becomes sane or when she is willing to accept the decision of the rabbinic tribunal. Consult Scheftelowitz 70.

${ }^{16}$ Scheftelowitz $69-70$. Compare note 15 and corresponding text. It is to be remembered that the possibility of censure and the refusal of rabbinical sanction is enough to deter religious husbands from acting contrary to the religious rulings.

${ }^{17}$ Horowitz 293.

${ }^{13}$ Proceedings of the Rabbinical Assembly of America 143 (1954). 
of the Jewish law of marriage throughout his or her lifetime. We authorize the Beth Din to impose such terms of compensation as it may see fit for failure to respond to its summons or to carry out its decision. ${ }^{19}$

Inclusion of this clause in the marriage contract is recommended as a preliminary to any marriage solemnized by a member of the Rabbinical Assembly. ${ }^{20}$ As worded, the clause seems to be an undertaking by each party to seek the counseling services of the Beth Din in case of marital difficulty, to recognize the power of the Beth Din to render decisions of binding effect concerning the duties of the parties to each other, and to enforce such decisions by the imposition of money penalties. In fact, however, the Beth Din is not to enter into all domestic controversies in the capacity of a marriage counselor. The scope of the agreement is limited to a "promise that should proceedings for civil divorce ever be instituted, either party may summon the other to the rabbinical court to demand a get [religious divorce], and that the rabbinical court may summon the other party (either before or after the civil divorce has been granted) for the sake of effecting a reconciliation or if that fails of arranging a get."

The problem which the agreement presents is the extent to which one may resort to civil courts when a religious body finds itself unable to protect the observant spouse. This comment will follow the marital life of a hypothetical couple and examine the possible or attempted uses of the agreement at various stages of the marriage.

Suppose that the wife is a devout Jewess and her husband is ostensibly a devout Jew. Shortly after the marriage, a dispute arises regarding religious behavior, and $H$ proclaims an intent which had existed before the marriage not to be bound by any antenuptial agreement purporting to bind him to the decision of a religious body. $W$, finding an assumption underlying her marriage to be non-existent, and regarding continuation of her marriage as a threat to her faith, therefore brings an action of annulment alleging that she was induced to conclude the marriage by H's fraud. Even though $W$ may succeed in proving, as required, that the fraudulent intent existed in her husband's mind at the time of the conclusion of the marriage; ${ }^{22}$ that she actually relied upon

${ }^{10}$ The official English translation of the Conservative Jewish Ketubah, ibid., at 67-68. The Ketubah is printed both in Hebrew-Aramaic and in English.

${ }^{20}$ Tbid., at 80.

2 From a form letter sent to all members of the Rabbinical Assembly of America by Rabbi Louis Finkelstein, Chancellor of the Jewish Theological Seminary of America, introducing the special Ketubah agreement, December 20, 1954, at page 3. Also consult Zucker, A Rabbi's Observation: The New Marriage Contract, 8 United Synagogue Review, No. 5, at 7 (March 1955); Bokser, The Ketubah and Conservative Judaism, 21 Jewish Frontier, No. $12(235)$, at 17 (December 1954). The general form of the agreement, not once referring to the purpose of procuring a religious divorce, is explained by the indelicacy of referring to possible divorce at the time of marriage. Letter of Rabbi Finkelstein, supra.

2 E.g., Anonymous v. Anonymous, 49 N.Y.S. 2d 314 (S.Ct., 1944). 
the agreement in consenting to the marriage; ${ }^{23}$ that the action of annulment is truly the result of her discovery of H's fraud; ${ }^{24}$ and that she left her husband immediately thereafter, ${ }^{25}$ in most jurisdictions she will be unable to obtain a decree of annulment. ${ }^{26}$ In Wells $v$. Talham, ${ }^{27}$ for example, a Roman Catholic husband brought an action to annul his marriage, alleging fraud in an antenuptial agreement which provided for a Roman Catholic ceremony following a Protestant ceremony, and also fraudulent representation by $\mathrm{W}$ that her former husband was dead. (Plaintiff's religious beliefs proscribed marriage with a divorced party while the divorced party's former spouse was still alive.) The court denied an annulment. Preserving the integrity of the marriage relation was considered of overbearing importance; therefore the representations alleged were held not to go to the essence of the marriage relation. The court, indicating that it was motivated by considerations of policy concerning the relationship between the state and denominational religious beliefs, said: "The question is raised whether members of one church can succeed in nullifying a marriage upon false representations when the same representation would afford no cause of action to members of other churches. We are not inclined to give our sanction to such a proposition."2s

The New York courts have adopted a different view. When an agreement for a religious marriage to follow a civil marriage ceremony is shown to have been made fraudulently, an annulment may be granted. ${ }^{29}$ As one New York

2 E.g., Rozsa v. Rozsa, 117 Misc. 728, 191 N.Y. Supp. 868 (S.Ct., 1922).

24 Taylor v. Taylor, 181 Misc. 306, 47 N.Y.S. 2d 401 (S.Ct., 1943) ; Bojara v. Bojara, 79 N.Y.S. 2d 627 (S.Ct., 1948).

${ }^{25}$ Taylor v. Taylor, 181 Misc. 306, 47 N.Y.S. 2d 401 (S.Ct., 1943) ; see Watkins v. Watkins, 197 App. Div. 489, 189 N.Y. Supp. 860 (1st Dep't, 1921).

${ }^{2}$ In order to entitle the deceived party to obtain an annulment, it is generally held that the fraudulent misrepresentation must relate to the "essentials of the marriage relation." Consult 55 C.J.S., Marriage $\$ 34 \mathrm{~b}$ (3) (1955). Few states, if any, have been as liberal as New York in the decreeing of annulments. Wells v. Talham, 180 Wis. 654, 660, 194 N.W. 36, 39 (1923) ; Note, 28 Ml. L. Rev. 124 (1933). Regarding the New York position, see notes 29 et seq. and corresponding text; compare Woronzoff-Daschkoff v. Woronzoff-Daschkoff, 303 N.Y. 506, 511, 104 N.E. 877, 880 (1952) (annulment not allowed where the fraud consisted of a promise by the husband to find a job after marriage, and a statement by him that he had never taken money from women) where the court said: "[W]hile we have, for better or worse, retreated [citations] from the old idea that marriages can be voided only for frauds going to the essentials of marriage, ... it is, nonetheless, still the law in New York that annulments are decreed, not for any and every kind of fraud [citing Mirizio v. Mirizio, discussed infra note 29] but for fraud as to matters 'vital' to the marriage relation only."

${ }^{2} 180$ Wis. 654,194 N.W. 36 (1923). The husband died and the suit was revived in the name of the executor of his estate.

${ }^{23}$ Tbid., at 664, 40.

${ }^{22}$ Aufiero v. Aufiero, 222 App. Div. 479, 226 N.Y. Supp. 611 (1st Dep't, 1928) (the parties had lived together before discovery of the fraud); Rozsa v. Rozsa, 117 Misc. 728, 191 N.Y. Supp. 868 (S.Ct., 1922) (unclear whether there had been cohabitation). Compare: Mirizio v. Mirizio, 242 N.Y. 74, 150 N.E. 605 (1926) (action for separate maintenance). In the Mirizio case, "Both parties were Catholics, and prior to the civil ceremony they agreed that a religious service should be performed in a Catholic church. The understanding that the mar- 
court has said: "The right of an individual to his religious conviction is so ingrained in our philosophy of government and life that courts hesitate not to give full credence to such a claim." 30 Where there has been a religious ceremony and the antenuptial promise is for a second religious ceremony, even the New York courts do not grant an annulment. ${ }^{31}$ Thus in a case ${ }^{32}$ which dealt with an alleged fraudulent promise to have a Roman Catholic ceremony after a Protestant ceremony, the court denied an annulment:

The parties in effect claim that they made a private agreement that in the future there would be a second ceremonial marriage. Logically, the plaintiff must claim that this was of such importance to her that if the promise were not kept, she would not consider herself married. The law does not recognize any such private agreement and it is difficult to see how a prohibited agreement can be recognized as the basis of a prenuptial fraud. 33

The New York courts have thus distinguished agreements for a subsequent religious marriage based on the type of original ceremony. Where there already has been one religious ceremony, canceling its effect for lack of a sec-

riage should not be consummated until the religious ceremony was performed [was] undisputed." 242 N.Y., at 89,150 N.E., at 611 . The court, holding in favor of the defendant, spoke in sweeping terms when considering the effect of breach of this agreement: "This plaintiff, with her religious scruples concerning the consummation of a marriage contract, had the situation in her own control. She was not obliged to submit to a civil marriage and then rely upon her husband to carry out a religious ceremony which would satisfy her scruples. . . . Public policy in such a vital matter as the marriage contract should not be made to yield to subversive private agreements and personal considerations." There were strong dissents by Crane and Lehman, JJ. The Mirizio case was carefully distinguished in the Aufiero case by pointing out the difference in the attempted use of the antenuptial agreement: "[T]he plaintiff there [in the Mirizio case] was not disavowing, but standing upon the civil contract, and seeking to enforce her rights thereunder." Supra, at 479-80,612. Where the marriage has not been consummated an annulment has been granted even outside of New York for fraud in the religious antenuptial agreement. Akrep v. Akrep, 1 N.J. 268, 63 A. 2d 253 (1949); Cart v. Cart, 28 N.Y.S. 2d 61 (S.Ct., 1941); Watkins v. Watkins, 197 App. Div. 489, 189 N.Y. Supp. 860 (1st Dep't, 1921) ; also see Babis v. Babis, 75 A. 2d 580 (Del. Super., 1950). In this situation the public interest in preserving the marriage has been found lacking in importance. E.g., Akrep v. Akrep, supra; see Hanson v. Hanson, 287 Mass. 154, 191 N.E. 673 (1934). On the other hand, the importance of the agreement to the marriage relation is here emphasized since the religious motive may have been the reason for the non-consummation of the marriage.

${ }^{30}$ Vonbiroganis (Von Brack) v. Von Brack, 64 N.Y.S. 2d 885, 887 (S.Ct., 1946). This is dictum. An annulment was not granted in this case; the wife had waited twelve years before bringing an action and therefore the good faith of her religious motives was doubted.

${ }^{31}$ Borgstedt v. Borgstedt, 188 Misc. 183, 67 N.Y.S. 2d 66 (S.Ct., 1946) ; Hubner v. Hubner, 188 Misc. 125, 67 N.Y.S. 2d 70 (S.Ct., 1946). Also see Samuelson v. Samuelson, 155 Md. 639, 142 Atl. 97 (1928). Compare Wells v. Talham, 180 Wis. 654, 194 N.W. 36 (1923) and discussion p. 125 supra, where the court made no distinction between a teligious ceremony following a civil ceremony or following another religious ceremony.

${ }^{32}$ Borgstedt v. Borgstedt, 188 Misc. 183, 67 N.Y.S. 2d 66 (S. Ct., 1946).

${ }^{33}$ Ibid., at 187,70 . In this case the marriage had been consummated and there was one child, a fact which may have made the court feel that the antenuptial promise was not regarded by the parties as essential to the marriage. Compare Taylor v. Taylor, 181 Misc. 306, 47 N.Y.S. 2d 401 (S.Ct., 1943). 
ond religious ceremony is tantamount to concluding that the first ceremony is not binding and that the second is superior. The courts will not choose between religions; ${ }^{34}$ once there has been a religious ceremony, the beliefs of the parties have been given their due respect. The policy of preserving the integrity of the marriage relation then becomes paramount.

In New York, fraud in an antenuptial promise to change religions has also been alleged as ground for an annulment. Here there is an additional consideration involved--the promisor's religious beliefs are the subject of the promise. His right to profess the religion of his choice must be respected. In Nilsen v. Nilsen, ${ }^{35}$ for example, the court declared:

It is alleged that the defendant promised to embrace the religion of the plaintiff and to adhere to the tenets thereof. To a reasonably prudent person, embracing a particular religion is not a matter of signing a book and paying dues. It involves some understanding and some acceptance of religious beliefs, moral law and forms of worship. People do not acquire these as they do a suit of clothes. People in good faith may attempt to adopt a particular religion and never succeed. Reason cannot encompass the supernatural. Divine faith is supernatural. It seems that the recognition of the alleged fraud in this case eventually would require the civil courts to undertake to solve problems and to answer questions which are outside the civil aspects of marriage and should be left with the parties and their respective religious affiliations for possible solution. ${ }^{36}$

In a case such as this where freedom of religious belief is directly involved and consequently there can be no reasonable reliance on the antenuptial promise, an annulment should not be granted..$^{37}$

It seems clear that in spite of some New York decisions, fraud in an antenuptial agreement to grant a religious divorce is not sufficient to support an annulment decree, since the agreement is generally not considered essential to the marriage relationship.

${ }^{3}$ Cf. Knibbs v. Knibbs, 121 Atl. 715 (N.J., 1923).

${ }^{35} 66$ N.Y.S. 2d 204 (S.Ct., 1946).

${ }^{38}$ Ibid., at 207 . This is dictum. The court held that the existence of the agreement was not proved.

${ }^{37} \mathrm{~A}$ divorce or separate maintenance may be sought by $\mathrm{W}$ because of the action of $\mathrm{H}$ regarding the antenuptial agreement. Generally a wife is allowed separate maintenance only if her husband has given her a statutory ground for divorce. E.g., Jones v. Jones, 233 Ala. 642, 173 So. 49 (1937) ; Hood v. Hood, 138 Md. 355, 113 Atl. 895 (1921); compare Wohlfort v. Wohlfort, $116 \mathrm{Kan}$. 154, 245 Pac. 746 (1924) (suit for separate maintenance allowed though the abandonment had not continued for a period sufficient for a divorce). Since by definition a divorce may be obtained only for misconduct occurring during marriage, a fraud committed before its conclusion cannot provide a ground for divorce in the absence of specific statutory provisions. Consult 27 C.J.S., Divorce $\$ 17$, at $n .87$ (1955). The court must therefore decide whether the particular action alleged in the complaint, apart from its religious significance, is comprehended within the given statutory terms, e.g., "fraud," Masciocchi v. Masciocchi, 72 D. \& C. 257 ( $\mathrm{Pa} ., 1950$ ) (divorce action); "desertion," Rosner v. Rosner, 108 N.Y.S. 2d 196 (Dom. Rel. Ct., 1951) (separate maintenance action); or "gross neglect of duty," Apple v. Apple, 28 Ohio N.P. (N.S.) 620 (1931) (divorce action). 
Thus far, cases where the religious agreement may have been indirectly invoked have been examined. The primary purpose of the new agreement, however, is to insure a religious divorce when a civil divorce is pending or has been issued. ${ }^{38}$ Suppose that $H$ sues for a civil divorce and $W$ requests the rabbinical court to issue its summons. ${ }^{30} \mathrm{H}$, however, may refuse to comply with the summons. ${ }^{40}$ If a civil divorce decree has not yet been issued, $W$ may use the antenuptial agreement as a defense to the divorce action; she may interpose the agreement to "arbitrate" as a condition precedent to the commencement of divorce proceedings in the secular court. ${ }^{41}$

It is generally held that unless an arbitration provision is specifically stated to be-or necessarily must be-a condition precedent to the right to sue, the

${ }^{38}$ Note 21 supra and corresponding text.

${ }^{39}$ Though its jurisdiction has been requested, the religious court may not agree to issue its summons and entertain the controversy. Even if $W$ can convince the secular court that the religious court or its ruling body is a third party to the marriage contract, she will find no relief in the civil courts to compel the ecclesiastical tribunal to entertain the case. The extent of the jurisdiction of the religious court in ecclesiastical matters is the exclusive decision of the religious tribunal or organization. Cf. Maxwell v. Brougher, 99 Cal. App. 2d 824, 222 P. 2d 910 (1950); Fusell v. Hail, 233 IIl. 73, 84 N.E. 42 (1908); see Ramsey v. Hicks, 174 Ind. 428, 91 N.E. 344 (1910). In Fusell v. Hail, supra, where the court denied the plaintiff's prayer for a decree declaring that an ecclesiastical body had no power to decide on a consolidation of two churches, the court said: "[F]reedom of religious profession and worship cannot be maintained if the civil courts may interfere in matters of church organization, creed, and discipline, construe the constitution, canons, or rules of the church, and regulate and revise its trials and the proceedings of its governing bodies. . . The civil courts offer no remedy for any abuse of ecclesiastical authority which does not violate a civil or property right." 233 III. 73, 77, 84 N.E. 42,44 (1908).

${ }^{10}$ As a result of his refusal to comply with the summons of the religious court, the rabbinical body may bring religious sanctions to bear against $H$. The civil courts will not enjoin the religious group from enforcing its order against $H$. Referring to church organizations with an ecclesiastical tribunal "for the decision of controverted questions of faith ... and for the ecclesiastical government," the United States Supreme Court has said: "All who unite themselves to such a body do so with an implied consent to this government, and are bound to submit to it. But it would be a vain consent and would lead to the total subversion of such religious bodies, if any one aggrieved by one of their decisions could appeal to the secular courts and have them reversed. It is of the essence of these religious unions, and of their right to establish tribunals for the decision of questions arising among themselves, that those decisions should be binding in all cases of ecclesiastical cognizance, subject only to such appeals as the organism itself provides for." Dictum in Watson v. Jones, 13 Wall. (U.S.) 679 , 729 (1871). Thus if $H$ wishes to retain the benefits of the religion and to keep his place within it, he must fulfill the laws of the organization and accept the burdens of his religion. He cannot claim "the benefit of the faith that [he] follows with the protection granted under its laws, and, in the next breath deny [his] allegiance to the body under which [he] serves." Canovaro v. Brothers of Order of Hermits, $326 \mathrm{~Pa} .76,82,191$ Atl. 140, 144 (1937); Cohen v. Silver, 277 Mass. 230, 178 N.E. 508 (1931). H's remedy here is not in the secular courts. "[H]aving identified himself with such a denomination, his remedy is either to appeal to the proper ecclesiastical superior of the [religious court], or, if so advised, to sever his connection with the organization." Bonacum v. Harrington, $65 \mathrm{Neb} .831,838$ (1902).

4 This would be a claim according to the general wording of the agreement rather than in accordance with the expressed purpose of the agreement. 
civil courts will not be ousted of their jurisdiction. ${ }^{42}$ There is no such condition explicit or necessarily to be implied from this antenuptial agreement. On the contrary, according to the Jewish standards, the marriage is not dissolved by the civil divorce. Therefore the antenuptial agreement remains in effect until a religious divorce has been completed regardless of the civil state of the marriage. Further, the civil court, in effect, is being asked to make the right of the husband to obtain a divorce contingent on an appearance before a religious group. In an analogous situation ${ }^{43}$ it has been said:

[A] judicial provision or requirement, which would make the promulgation of a decree of divorce, to which the [husband] is entitled, as a "civil right," conditioned upon his consent to supplement the legally recognized civil contract, by a religious ceremonial marriage, according to the rubrics of a church of which he is not a member, and whose religious tenets he is conscientiously unwilling to accept, is tantamount to the denial of due process of law, as well as in contravention of the constitutional inhibition which insures to him the protection of his "civil rights," regardless of his "religious principles." 44

$\mathrm{W}$ may be forced, therefore, to institute an action for specific performance $\mathrm{e}^{45}$ of $H$ 's agreement to appear before the religious court. $W$ is not asking that H's beliefs be channeled toward any particular religion, but only that the court enforce the performance of an external, formal act which he at one time agreed to do. From W's point of view, the act requested is only mechanical because: (1) Mere appearance before the rabbinical court demands no acceptance of the religious authority of any particular group beyond that which was once manifested; (2) the act of giving a Jewish divorce does not demand subscription to any particular set of beliefs; $;^{46}$ (3) the time element involved in appearing before a religious court and giving the divorce "is not much out of a lifetime, especially if it will bring peace of mind and conscience to one whom [the husband] must at one time have loved."47 Indeed, it seems highly inequitable to allow the husband to take advantage of his wife's conscientious beliefs by allowing him to hide behind the phrase "religious freedom"; espe-

12 Cf. Palmer v. Fix, 104 Cal. App. 562, 286 Pac. 498 (1930) ; Big Vein Pocahontas Co.v. Browning, 137 Va. 34, 120 S.E. 247 (1923) ; Flavelle v. Red Jacket Consol. Coal and Coke Co., 82 W. Va. 295, 96 S.E. 600 (1918).

${ }^{4} \mathrm{Knibbs}$ v. Knibbs, 121 Atl. 715 (N.J., 1923) (a wife claimed, as a defense to a charge of desertion in a divorce action, that the husband was required to fulfill his antenuptial promise calling for a religious marriage ceremony).

"Ibid., at 718.

${ }^{25}$ The injury to $W$ as a result of H's breach of the antenuptial agreement has no monetary equivalent. Therefore, even if a legal wrong is established, the loss incurred is such that compensatory damages cannot be awarded therefor. Under these circumstances, courts will award nothing more than nominal damages. Cf. News Leader Co. v. Kocen, 173 Va. 95, 3 S.E. 2d 385 (1939); Cut Rate Drug Co. v. Scott \& Gilbert Co., 54 Nev. 407, 20 P. 2d 651 (1933). Nominal damages, of course, do not assure $W$ of her right to remarry according to her beliefs.

${ }^{18}$ The divorce procedure is described supra n. 8.

" Koeppel v. Koeppel, 138 N.Y.S. 2d 366, 373 (S.Ct., 1954). 
cially where, as here, freedom of religion is most probably invoked by the husband solely to allow him to extort money from the wife.

However, there is a very persuasive argument for denying specific enforcement of the antenuptial agreement. Such action would rquire $H$ to submit to a court conducted by a religious authority in which he may no longer believe and might, therefore, infringe his constitutional right to practice freely the religion of his choice. The United States Supreme Court has said:

The "establishment of religion" clause of the First Amendment means at least this: Neither a state nor the Federal Government can set up a church. Neither can pass laws which aid one religion, aid all religions, or prefer one religion over another. Neither can force nor influence a person to go to or remain away from church against his will or force him to profess a belief or disbelief in any religion. No person can be punished for entertaining or professing religious beliefs or disbeliefs, for church attendance or non-attendance. 48

The granting of a religious divorce, moreover, is an act regulated by religious laws and of importance only within the particular religion. ${ }^{49}$

Such are the arguments for and against specific performance of the antenuptial agreement. Only two cases have been found dealing with the legal effect of an agreement to give a religious divorce..$^{50}$ In one,,$^{51}$ an action for

${ }^{45}$ Everson v. Board of Education, 330 U.S. 1, 15-16 (1947) (emphasis added). That the action of a state court in enforcing the antenuptial religious agreement is tantamount to action by the state itself, cf. Shelley v. Kraemer, 334 U.S. 1, 14-16 (1947). However, the agreement standing alone, voluntarily entered into and kept, is not violative of any rights guaranteed $\mathrm{H}$ by the Constitution. Cf. Shelley v. Kraemer, supra, at 12.

${ }^{49}$ Regarding religious observances the United States Supreme Court has said: "The government must be neutral when it comes to competition between sects. It may not thrust any sect on any person. It may not make any religious observance compulsory. It may not coerce anyone to attend church, to observe a religious holiday, or to take religious instruction." Dictum in Zorach v. Clauson, 343 U.S. 306, 314 (1952).

${ }^{50}$ Koeppel v. Koeppel, 138 N.Y.S. 2 d 366 (S.Ct., 1954) ; B. v. B., 57 R.G.Z. 250 (German S.Ct., 1904). There is one situation in which our courts have occasionally been asked to enforce specifically a contract calling for a religious act. When a Roman Catholic priest offciates over a mixed marriage, the couple must sign an agreement to raise the children in the Roman Catholic faith. Such agreements, the subject of several actions for specific performance, have never been enforced. The welfare of the child is the overriding and determining factor here. Boerger v. Boerger, 26 N.J. Super. 90, 97 A. 2d 419 (1953) ; Shearer v. Shearer, 73 N.Y.S. 2d 337 (S.Ct., 1947) ; Ramon v. Ramon, 34 N.Y.S. 2d 100 (Dom. Rel. Ct., 1942); Commonwealth ex rel. Stack v. Stack, 141 Pa. Super. 147, 15 A. 2 d 76 (1940) ; In re Butcher's Estate, 266 Pa. 479, 109 Atl. 683 (1920); Denton v. James, 107 Kan. 729, 193 Pac. 307 (1920); Commonwealth v. McClelland, 70 Pa. Super. 273 (1918); Brewer v. Cary, 148 Mo. App. 193, 127 S.W. 685 (1910); In re Luck, 10 Ohio Dec. 1 (Prob. Ct., 1900). Of these cases, a few contain dicta supporting the enforcement of the religious antenuptial agreement involved. Shearer v. Shearer, supra; Ramon v. Ramon, supra; Denton v. James, supra; Commonwealth v. McClelland, supra; In re Luck, supra. Two courts talked of the unenforceability of such an agreement because of the controlling effect of the free exercise of religion. Boerger v. Boerger, supra; Brewer v. Cary, supra. The latter viewpoint seems more correct in view of the discussion in the text.

ro Koeppel v. Koeppel, 138 N.Y.S. 2d 366 (S.Ct., 1954). 
annulment of marriage had been instituted, and an agreement was formulated and signed to become effective if the marriage was annulled. The agreement contained the following provision:

Upon the successful prosecution of the Wife's action for the dissolution of her marriage, the Husband and Wife covenant and agree that he and she will, whenever called upon, and if and whenever the same shall become necessary, appear before a Rabbi or Rabbinate selected and designated by whomsoever of the parties who shall first demand the same, and execute any and all papers and documents required by and necessary to effectuate a dissolution of their marriage in accordance with the ecclesiastical laws of the Faith and Church of said parties. ${ }^{52}$

Though the marriage was annulled, the husband refused to appear before a rabbi or a rabbinic court. The wife then brought an action for specific performance of the part of the agreement quoted. The husband claimed that a decree of specific performance would interfere with his freedom of religion under the Constitution. The court held:

Complying with his agreement would not compel the [husband] to practice any religion, not even the Jewish faith to which he still admits adherence. . . . His appearance before the Rabbinate to answer questions and give evidence needed by them to make a decision is not a profession of faith. Specific performance herein would merely require the defendant to do what he voluntarily agreed to do. ${ }^{53}$

The other case was decided by the Supreme Court of Germany half a century ago. ${ }^{54}$ The principles expounded in that opinion seem persuasive under our own laws. ${ }^{55}$ The husband, in connection with a settlement concerning alimony and property rights agreed to appear before the rabbinic board and there to give his former wife a Jewish letter of divorcement. He subsequently refused to fulfill his agreement. The wife obtained specific enforcement in the lower court. The supreme court reversed. Concerning appearance before a religious body and there executing and delivering a letter of divorcement in the form provided by the Jewish religion, the court said:

[T] here do not exist, at the present time, any legal norms pertaining to marriage other than those promulgated by the state. Accordingly, we must dismiss the Appellate Court's idea that the declarations and the acts prescribed by the Jewish religion for the ritual divorce are "by and large" or "predominantly" or . . . even "exclusively" of a legal nature. ... They are, if still adhered to, acts of a purely religious nature. From that fact it immediately follows that the execution of such acts by way of legal coercion is not within the reach of the state. Now that the state has defined the borderline between its own sphere and that of religion, neither is to encroach upon the sphere of the other. In the realm of religion the binding force of obligations is a matter of conscience and spirit, and the fulfillment of such obligations is a religious and ethical duty. In this sphere there does not and may not exist a legal binding of the will. ... Hence, in including in a contract of private law the husband's promise

${ }^{62}$ Tbid., at 369-70.

Ibid., at 373. st B. v. B., 57 R.G.Z. 250 (German S.Ct., 1904).

* Compare note 49 supra. 
to consent to a religious divorce, the parties have, mistakenly, agreed upon a subjectmatter which does not lend itself to a legal transaction; they have, therefore, entered into a contract legally impossible of performance.. .56

Implicit in the New York court's decision is the idea that mere appearance before the rabbinical court involves only the recognition of a commitment voluntarily made to perform a ministerial act. On the other hand, if the reasoning of the German court is accepted, enforcement of the granting of a religious divorce is not within the power of a state or its courts; the giving of the religious divorce is "religious observance." 57

If the cases are to be reconciled, a distinction must be made between requiring only an appearance before a meeting of a religious tribunal-the New York court talked in these terms-and the actual granting of a religious divorce-the problem the German court considered. It is difficult to maintain this distinction; in both cases the act involved is the result of a religious rule or law, and as such both may be considered religious acts. On the other hand, the act in each case demands no prayer, blessing, or belief of special religious significance; from this point of view the acts are mechanical. If "absolute" freedom of religion is regarded as a goal which cannot be sacrificed in favor of reasonable contractual expectations, the German court's position cannot be assailed. If, on the other hand, protection of contractual rights here is deemed consistent with a proper degree of religious freedom, the New York court's position is acceptable. The choice between the competing alternatives would appear to be a policy decision.

${ }^{60}$ Translation from Rheinstein, Comparative Law of Contracts 6-7 (1944).

${ }^{57}$ See Zorach v. Clauson, 343 U.S. 306, 314 (1952).

\section{THE PRE-THORLEY $V . K E R R Y$ CASE LAW OF THE LIBEL-SLANDER DIŚTINCTION}

There is no question that the distinction between libel and slander was firmly imbedded in our law in 1812 by Sir James Mansfield's decision in Thorley $v$. Kerry. ${ }^{1}$ Since then the distinction has become one of the best known and most consistently criticized technicalities in the law. Only occasionally has any effort been made to rationalize it, ${ }^{2}$ and the few arguments

${ }^{1} 4$ Taunt. 355, 128 Eng. Rep. 367 (C.P., 1812); also reported in 3 Camp. 214, 170 Eng. Rep. 1358.

2E.g., Cardozo, "The schism in the law of defamation between the older wrong of slander and the newer one of libel is not the product of mere accident. ... It has its genesis in evils which the years have not erased. ... What gives the sting to the writing is its permanence of form. The spoken word dissolves, but the written one abides and "perpetuates the scandal." " Ostrowe v. Lee, 256 N.Y. 36, 39, 175 N.E. 505, 506 (1931). 